\title{
The Impact of Oil Prices on the G7's Inflation Rate: An Econometric Study for the Period (1986-2016)
}

\author{
Hmood Humaidi Banikhalid ${ }^{1}$ \\ ${ }^{1}$ Faculty of Business, Tafila Technical University, Tafila, Jordan \\ Correspondence: Hmood Humaidi Banikhalid, Faculty of Business, Tafila Technical University, AT-Tafila, P.O. \\ Box 179, Tafila, 66110, Jordan. E-mail: hmoodhmeadi@gmail.com
}

Received: April 12, 2017

Accepted: April 26, 2017

Online Published: May 20, 2017

doi:10.5539/ijef.v9n6p167

URL: https://doi.org/10.5539/ijef.v9n6p167

\begin{abstract}
The study aims at determining the impact of oil prices on the G7 inflation rate, and examining the nature of that impact, whether negative or positive, if existed, during the period from November 1986 to October 2016.

The study found that there is a statically significant impact of the oil prices on the G7 inflation rate, and that the relationship between the two variables is not linear: the rate of inflation is affected by oil pricesat price levels below (34.5)\$ per barrel negatively. And after this level, the relationship turns positive.
\end{abstract}

Keywords: Inflation rate, G7, Oil prices

\section{Introduction}

The productive economic activity of man is based on energy. There is no agriculture or industry without energy sources. This is also reflected on consumer and reciprocal activity. Oil remains the main source of energy and it's a raw materialfor thousands of industrial products.In light of the fluctuation of the prices of this material between ups and downs, that sometimes exceeds (1000\%), this material becomes a major factor in the destabilization of world economy. Economic stability, in its general concept, is avoiding sharp fluctuations in macroeconomic variables, and perhaps the most important economic variable, that issensitive to oil prices, is inflation rate.

Is the modern world capable of absorbing these shocks in oil prices? Are the different economies able to achieve the goal of economic stability in light of these fluctuations in the prices of the main source of energy? The first countries to absorb these effects are the G7 countries, which top the modern human evolution,because of their diversity in economic construction, knowledge of crisis coping-mechanisms, as well as security and economic stability that make them capable of achieving economic stability. Therefore, we define the problem with the following question: What is the impact of oil prices on G7 inflation rates?

In fact, most previous studies have found a strong positive effect of oil prices on inflation rate. According to Valadkhani and Mitchell (2002) there is a direct impact of high oil prices on Australia's consumer price index. This finding agreed with the results of a number of studies conducted on other economies, such as: (Khair al-Din, 2008) study on the Jordanian economy, (Bin Sabia', 2010) study on the Algerian economy, (Ahmad \& Rahim, 2013) study on the Pakistani economy, (Misati, 2013) on the Kenyan economy as well as the (Adam, 2016) study on the Indonesian economy, Theresearchers pointed out in the last study that the rise in oil prices by (1\%) will lead to an increase in inflation rates by $(0.33 \%)$.

This matter has not been proven at the utmost. A number of studies have shown that the impact of oil prices on the rate of inflation is limited, including (Leblanc \& Chinn, 2004) study, which was conducted on the economies of: the United States, the United Kingdom, France, Germany and Japan. The study pointed out that the impact of oil prices on inflation in these countries is similar and limited as the increase in oil prices by $10 \%$ will lead to a rise in inflation rate between $(0.1 \%)$ to $(0.8 \%)$ in both the United States and the European Union. This finding coincided with the results of a number of studies, including: (Jongwanich \& Park, 2011) study on a number of Asian developing countries and (Basnet \& Upadhyaya, 2015) study on ASEAN countries, in which the researchers pointed out that there is a limited impact of oil prices on inflation in these countries except for Thailand. (Mantai \& Alom, 2016) study found that there is no statistically significant effect of oil prices on inflation rate in Malaysia.

So, this study aims at explaining the impact of oil prices on the rate of inflation. The study is especially 
important in the $\mathrm{G} 7$ for several reasons, including:

- The variables of the study are important: Oil is the main source of energy, and the rate of inflation is the most prominent indicators of economic stability.

- The study is a case study on the G7 economies, which has the potential to be the world's most capable of achieving its economic objectives of efficiency, justice, growth and stability.

To achieve this objective, the researcher tested the hypothesis that says "Oil prices have a positive effect on the G7 inflation rate" by designing anEconometric model based on determining the impact of oil prices - represented by the simple average of oil prices for Brent, West Texas and Dubai- on the inflation rate - represented by the average of the consumer price index (CPI) in the G7 countries: France, Germany, Italy, Japan, United Kingdom, United States of America and Canada. The study was applied during the period (November 1986 - October 2016) on a monthly basis.

\section{Theoretical Framework}

\subsection{Oil Prices}

In our modern world, oil is the second strategic commodity after water (Ayoub, 2002, p. 5). It is considered the primary source of energy. Energy in its general sense is the main operator of global economic activity. It is impossible to imagine factories, farms, houses, hospitals, transportation and other activities without using one source or more of energy. Oil is a significant part of international trade (Mkhalafi, 2011, p. 1). Oil is the raw material for the manufacture of at least 11,000 commodities such as fertilizers, rubber, cosmetics, detergents and plastics (Mkhalafi, 2011, p. 2).

As a result of the importance of oil in the economy in general, the fluctuations of oil prices have great economic effects on importing and exporting countries. Importing countries are positively affected by the decline in oil prices because they get cheap energy, so, the costs of energy inputs decline, and the decline falls on final goods, whether they are directly produced by petroleum, such as petrochemicals, or indirectly, such as agricultural commodities (Al-Khater, 2015, p. 8). Oil in the exporting countries is considered the main source of the most important macro and micro economic indicators depending on the diversity of the economies of these countries (Ayoub, 2002, p. 9).

Through examining oil prices during the years of study, it is noticed that there is very volatile fluctuation as shown in Figure (1). The lowest price in this period was recorded during December 1998 as it reached about (10) $\$$, and in less than a decade, the highest price was recorded during July 2008, exceeding (140)\$, soon it fell below the (30)\$ level at the beginning of 2016.

We can distinguish between the following sharp fluctuations in the price of crude oil:

- The sharp fall in prices in the late 1990s due to the discovery of new oil production areas outside OPEC and major producers such as the North Sea area and Central Asia as well as an increase in global crude oil inventories unexpectedly (Ayoub, 2002, p. 10).

- Oil prices rose from 2002 to 2008 due to high economic growth rates in both China and India, coupled with a shortage in oil supplies due to unrest in the Middle East, especially Iraq (Al-Khater, 2015, p. 3).

- The sharp fall in prices as of 2014 due to the economic recession in the Euro-zone and the slowdown in growth in Asia especially China as well as the increase of oil shale production in the United States (Al-Khater, 2015, p. 4).

It is noted that fluctuations in oil prices are linked to the demand and supply. In the demand side standsthe level of global economic activity and its fluctuation between promotion and the crisis, especially in the countries that import oil the most, in addition to the climate factors whether the seasons are cooler or warmer. New oil discoveries, new energy alternatives, producer policies as well as crises and political and security tension in exporting countries stand in the side of supply. 


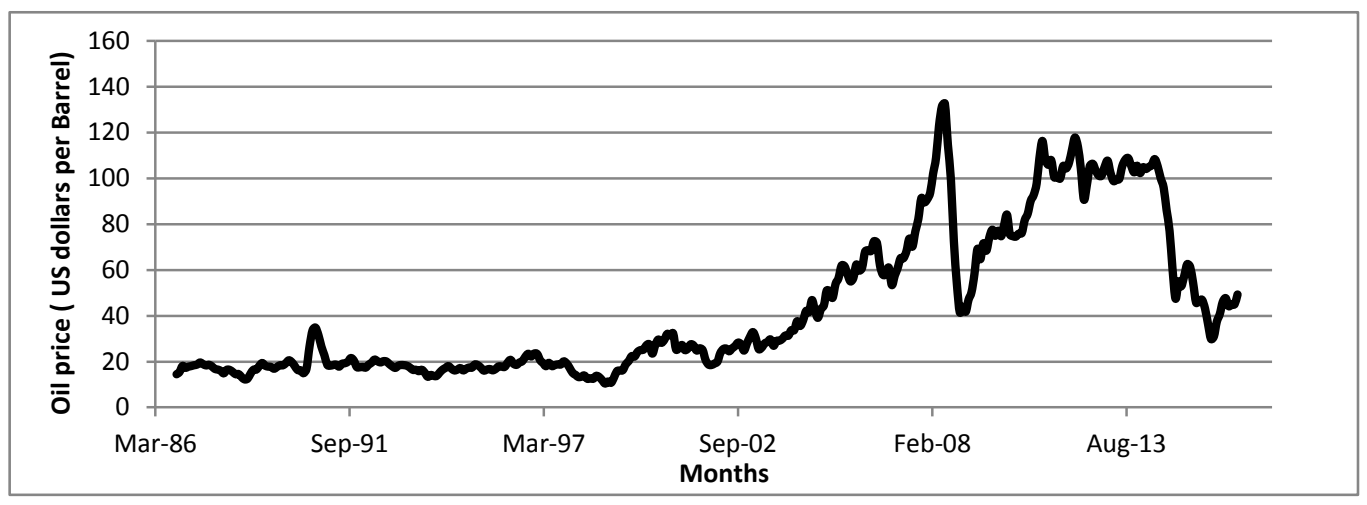

Figure 1. Average of oil prices during the period (1986-2016)

Note. The simple average of oil prices for each of Brent, West Texas and Dubai on a monthly basis in US dollar, source: indexmundi site (specialized in reviewing major global indicators in a number of sectors including the economic one) 12/2/2017 http://www.indexmundi.com/commodities/?commodity=crude-oil\&months=360

\subsection{Inflation in $G 7$ Countries}

The Inflation is the continuous rise in the overall level of prices. This phenomenon usually results from the overall demand for aggregate supply as a result of population increase or increase in money supply. Sometimes the reason is due to higher production costs such as higher raw material prices, labor costs or higher energy prices (Al-Wadi, 2013, p. 181). The reason also includesthe global rise in oil prices as occurred in Europe and the United States of America as a result of the shock of the first oil prices in the period after 1973 (Ma'rouf, 2005, p. 195).

As for inflation in the G7, we note from Figure (2) that inflation rates were limited during the years of study (1986-2006) between $(-1.4 \%)$ by the minimum level and $(5.5 \%)$ by the maximum level while the average for the period was (2.2\%). The following periods can be distinguished:

- From November 1986 to November 1990, this period was characterized by a continuous rise in inflation rates until inflation rate reached $(5.5 \%)$ at the end of this period.

- From December 1990 to March 1999, this period was characterized by a steady decline in inflation rates until they reached the levels of 1986.

- From April 1999 to August 2007, in this period thefluctuationwas limited as theaverage of the growth of inflation rate was close to zero $(0.01 \%)$.

- From September 2007 to August 2011, this period was marked by sharp fluctuations in inflation rates between rise and fall. The inflation rate was (4.6\%) in July 2008 and then dropped to (-1.4\%) in July 2009 , then jumped to (3.2\%) at the end of this period.

- From September 2011 to the end of the study period (October 2016), inflation rates declined to zero in mid-2015.

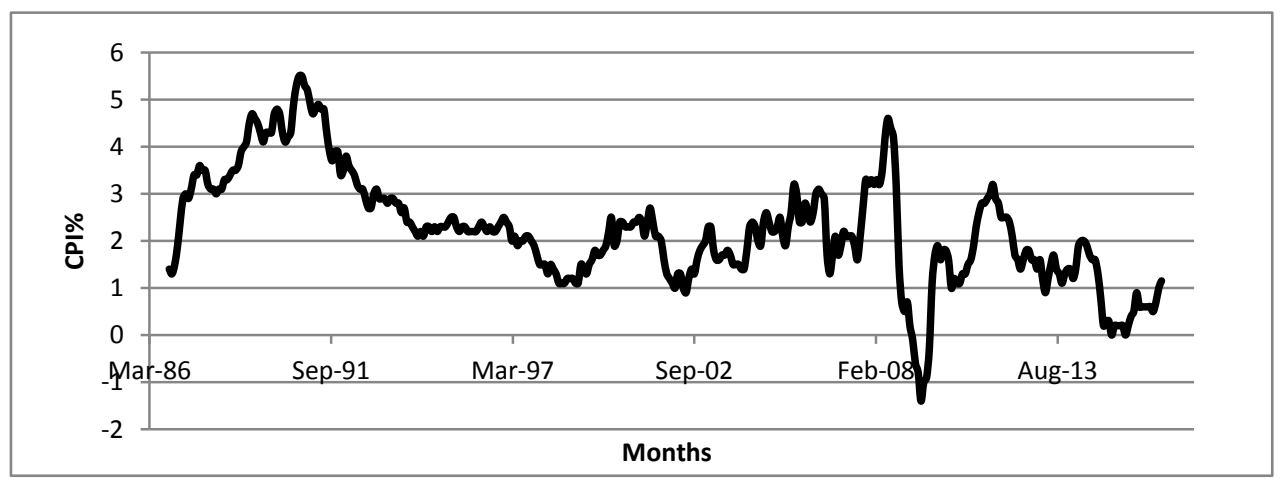

Figure 2. Inflation in the G7

Note. Source: the website https://data.oecd.org/price/inflation-cpi.htm 12/2/2017. 


\section{The Econometric Study}

\subsection{Variables}

The study model consists of two variables, which can be presented as follows:

- Oil prices: The researcher has adopted the prices of crude oil (petroleum) by calculating the simple average of oil prices for Brent, West Texas and Dubai on a monthly basis and in US dollar (Note 1).

- Inflation rate of G7: The researcher used the average of consumer price index (CPI) in the G7 countries: France, Germany, Italy, Japan, United Kingdom, United States of America and Canada (Note 2).

\subsection{The Econometric Model}

The researcher created a simple linear regression model represented by the following function:

$$
\begin{gathered}
I R=f(O P) \\
I R_{i}=\alpha+\beta O P_{i}+\mu_{i}
\end{gathered}
$$

Where: (IR) is inflation rate in the G7 and the dependent variable. The (OP) is oil price, an independent variable. The $(\mu)$ is the random variable.

\subsection{The Statistical Analysis}

The researcher evaluated $\beta$ by using the ordinary least squares (OLS) method, and its significance was tested using the $\mathrm{T}$ test, assuming that the results were significant if $\alpha$ was less than (0.05). The statistical package SPSS was used. The results were as in Table (1), and were consolidated with $\mathrm{R}^{2}$ coefficient.

Table 1. Statistical results showing the impact of oil prices on the rate of inflation

\begin{tabular}{ccc}
\hline R Square & $\boldsymbol{\beta}$ & Sig. \\
\hline 0.040 & -0.007 & $\mathbf{0 . 0 0 0}$
\end{tabular}

It is noticed that the dependent variable was negatively affected by the independent variable in term $(\alpha=0.000)$. To support the result, the researcher conducted a number of additional statistical analyzes:

- First: based on the assumption which says that the effect of the independent variable on the dependent is positive not negative, but this effect may not be synchronized, a dynamic study was conducted to determine the effect of the oil price in month $t$ on the G7 inflation rate in the third month $t+3$, then in the sixth month $t+6$, then in the ninth month $t+9$, then in the twelfth month $t+12$, so the researcher created a standard model represented by the following functions

$$
\begin{gathered}
I R_{t+3}=\alpha+\beta O P_{t}+\mu_{t} \\
I R_{t+6}=\alpha+\beta O P_{t}+\mu_{t} \\
I R_{t+9}=\alpha+\beta O P_{t}+\mu_{t} \\
I R_{t+12}=\alpha+\beta O P_{t}+\mu_{t}
\end{gathered}
$$

Where: $\left(\mathrm{IR}_{\mathrm{t}+3}\right)$ is Inflation rate in the third month. $\left(\mathrm{IR}_{\mathrm{t}+6}\right)$ is inflation rate in the sixth month. $\left(\mathrm{IR}_{\mathrm{t}+9}\right)$ is inflation rate in the ninth month. $\left(\mathrm{IR}_{\mathrm{t}+12}\right)$ is inflation rate in the twelfth month. $\mu$ is the random variable.

It is noticed that the result (Table 2) confirms the negative impact of oil prices on the inflation rate in the G7 in terms of $\left(\beta_{\mathrm{t}+3}=-0.008, \beta_{\mathrm{t}+6}=-0.011, \beta_{\mathrm{t}+9}=-0.013, \beta_{\mathrm{t}+12}=-0.017\right)$. The responsibility of the independent variable for the changes in the dependent variable increases by time in terms of $\left(\mathrm{R}_{\mathrm{t}+3}^{2}=0.054, \mathrm{R}_{\mathrm{t}+6}^{2}=0.091, \mathrm{R}_{\mathrm{t}+9}^{2}=0.134\right.$, $\left.\mathrm{R}_{\mathrm{t}+12}^{2}=0.228\right)$.

Table 2. Results of the dynamic study showing the impact of oil prices on inflation

\begin{tabular}{ccccc}
\hline Independent variable & Dependent variable & R Square & $\boldsymbol{\beta}$ & Sig. \\
\hline $\mathrm{OP}_{\mathrm{t}}$ & $\mathrm{IR}_{\mathrm{t}+3}$ & 0.054 & -0.008 & $\mathbf{0 . 0 0 0}$ \\
$\mathrm{OP}_{\mathrm{t}}$ & $\mathrm{IR}_{\mathrm{t}+6}$ & 0.091 & -0.011 & $\mathbf{0 . 0 0 0}$ \\
$\mathrm{OP}_{\mathrm{t}}$ & $\mathrm{IR}_{\mathrm{t}+9}$ & 0.134 & -0.013 & $\mathbf{0 . 0 0 0}$ \\
$\mathrm{OP}_{\mathrm{t}}$ & $\mathrm{IR}_{\mathrm{t}+12}$ & 0.228 & -0.017 & $\mathbf{0 . 0 0 0}$ \\
\hline
\end{tabular}

- $\quad$ Second: assuming that the relationship between the two variables is not linear, we draw the inflation 
curve in the G7 countries based on oil prices. As in Figure 3, the relationship is not linear and is closer to the quadratic coupling. Inflation levels are high at low oil prices, Inflation rates begin to decline as oil prices rise to a certain level as the relationship turns into a positive one. As oil prices rise, inflation rates rise.

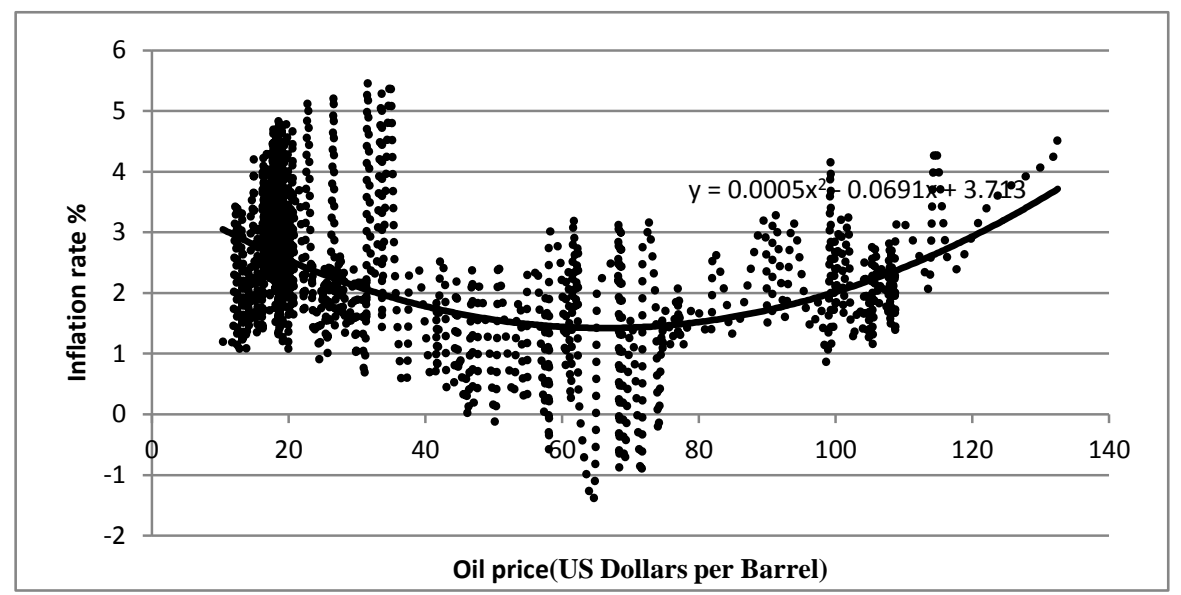

Figure 3. Non-linear relationship between inflation rates and oil prices

This requires us to repeat the statistical analysis by assuming that the relationship between the variables is nonlinear, so that we obtain the following results (see Table 3):

1). The relationship between the two variables is not linear in terms of $\left(R_{\text {linear }}^{2}=0.040\right),\left(R^{2}{ }_{\text {Quadratic }}=0.174\right)$.

2). The independent variable interprets $(17.4 \%)$ of changes of the dependent variable.

$3)$. The relationship between the two variables is medium in terms of $(R=0.417)$.

4). The relationship between the two variables is quadratic, the critical value is (34.5) in terms of the first derivative equals zero, and it is a minimum value in terms of the second derivative equals a positive value.

Table 3. Results of testing the relationship form

\begin{tabular}{|c|c|c|c|c|c|c|c|c|}
\hline \multicolumn{9}{|c|}{$\begin{array}{l}\text { Model Summary and Parameter Estimates } \\
\text { Dependent Variable: Inflation (CPI) }\end{array}$} \\
\hline \multirow[t]{2}{*}{ Equation } & \multicolumn{5}{|c|}{ Model Summary } & \multicolumn{3}{|c|}{ Parameter Estimates } \\
\hline & R Square & $\mathrm{F}$ & df1 & df 2 & Sig. & Constant & b1 & b2 \\
\hline Linear & .040 & 14.944 & 1 & 358 & .000 & 2.556 & $-.007-$ & \\
\hline Quadratic & .174 & 37.534 & 2 & 357 & .000 & 3.713 & $-.069-$ & .001 \\
\hline
\end{tabular}

The independent variable is Oil Price.

Inflation (CPI)

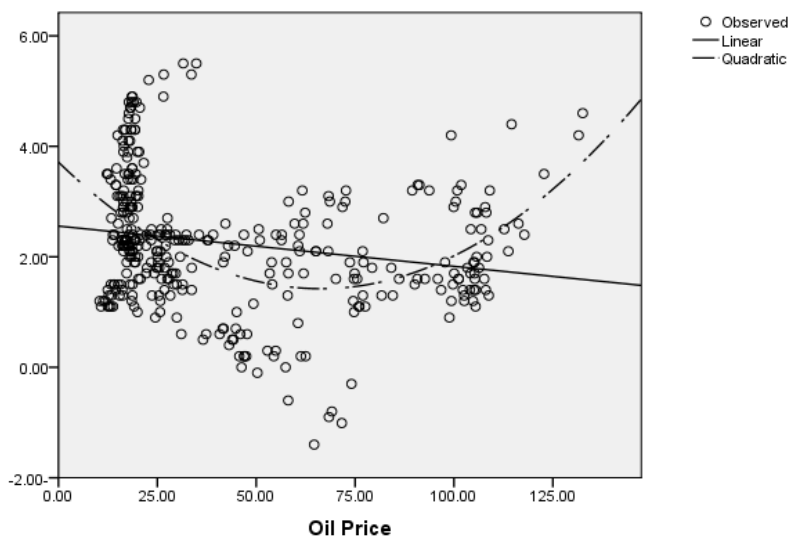




\subsection{Analysis of the Results}

Through the previous standard study we reach the following results:

1). Oil prices have a statistically significant effect on inflation rates of the $G 7$, and they are responsible for (17.4\%) of changes in G7 inflation rates, and thus accept the hypothesis that says "Oil prices have a statistically significant effect on inflation rate In the G7".

2). Inflation rates in the G7 are negatively affected by oil prices at price levels of $\$$ (34.5) per barrel and less, and then the direction of the relationship will be reflected positively in price levels that exceed that.

The impact of oil prices on the G7 inflation rates is justified by the fact that oil remains the mainstay of energy used in economic activity. In addition to being the raw material for many commodities, It enters the cost structure in a double way, making its prices significantly affect the prices of other goods and services.

It is obvious that thedirection of this impactis positive. If oil prices rise, production costs rise and inflation rates rise too, and that is called Cost-Push Inflation, and that was proved by this study at levels of oil prices above the level of (\$ 34.5) per barrel.But what needs to be explained and studied in depth is the negative impact of oil prices on inflation rates at low levels of oil prices, why do inflation rates rise when oil prices fall below this level?!

The split of the positive correlation between inflation and oil prices at low levels of its prices can be explained by distinguishing between the two main reasons for the general rise in prices: Cost-Push and Demand-Pull. The Cost-Push is represented by the increase in oil prices as the cost of production, While the Demand-Pull is determined by the effect of oil prices on real incomes. Excluding rent economies, each of the two effects works in the opposite direction of prices, when oil prices rise, costs rise and push prices to rise. But on the other hand, real incomes decrease, so, overall demand decreases and pushes prices to decline.Therefore, the Cost-Push has the biggest impact in theintermediate and high levels of oil prices, while we find thisimpact pulls back in front of the withdrawal of the demand of low oil prices.

At the level of \$ (35) per barrel and less, lower oil prices mean increasing the real incomes of individuals, which also means increasing the overall demand. So, the impact of the withdrawal of demand shows up to withdraw the general level of prices to rise. In the opposite direction, if prices rise in the lower range of this level, real incomes decline, then the overall demand decreases pushing the general level of prices to decline.

Thus, the intermediate levels of oil prices are useful for economic stability in the G7 countries, where the level of the inflation is acceptable.

\section{References}

Adam, P. (2016). A Model of the Dynamics of the Effect of World Crude Oil Price and World Rice Price on Indonesia's Inflation Rate. Agris On-Line Papers in Economics \& Informatics, 8(1), 3-12. https://doi.org/10.7160/aol.2016.080101

Ahmad, Z., \& Rahim, Y. (2013). The Influence of Dollar, Gold, and Petrol Prices on Inflation. Abasyn University Journal of Social Sciences, 6(2), 16-33.

Al-Khater, K. (2015). The Challenges of Oil Price Crises and Economic Diversification in the GCC States. Arab Center for Research and Policy Studies, Doha.

Al-Wadi, M. (2013). Macroeconomics (3rd ed.). Dar al-Masirah, Amman.

Ayoub, M. (2002). Towards an Arab oil policy. The Zayed Center for Coordination and Follow-up, United Arab Emirates.

Basnet, H. C., \& Upadhyaya, K. P. (2015). Impact of oil price shocks on output, inflation and the real exchange rate: Evidence from selected ASEAN countries. Applied Economics, 47(29), 3078-3091. https://doi.org/10.1080/00036846.2015.1011322

Berjas, H., \& Muhammad, M. (2000). International Conflict on Arab Oil (1st ed.). Besan for Publishing and Media Distribution.

Bin Sabe'a H. (2012). The effects of oil price shocks on some macroeconomic variables, Money supply, government expenditure, unemployment, and inflation in Algeria. Economic study: 1970-2010. unpublished master thesis, University of Algiers, Algeria.

Doweiri, M. (1983). Lectures in Petroleum Economics. University of Annaba, Office of University Publications, Algeria. 
Indexmundi.

(2017,

February

12).

Retrieved

from http://www.indexmundi.com/commodities/?commodity=crude-oil\&months=360

International Energy Agency. (IEA). Report 2011. Key World Energy Statistics.

Jongwanich, J., \& Park, D. (2011). Inflation in developing Asia: pass-through from global food and oil price shocks. Asian-Pacific Economic Literature, 25(1), 79-92. https://doi.org/10.1111/j.1467-8411.2011.01275.x

Khairuddin, M. (2008). The Influence of Oil Price Fluctuations on Inflation and Trade Balance in Jordan. Unpublished Master Thesis, University of Jordan.

LeBlanc, M., \& Chinn, M. D. (2004). Do High Oil Prices Presage Inflation? Business Economics, 39(2), 38-48.

Ma'rouf, H. (2005). Macroeconomic Analysis (1st ed.). Amman: Dar Safa for Publishing and Distribution.

Mantai, M. M., \& Alom, F. (2016). Impacts of oil price, exchange rate and inflation on the economic activity of Malaysia. OPEC Energy Review, 4O(2), 180-191. https://doi.org/10.1111/opec.12073

Misati, R. (2013). Commodity price shocks and inflation in a net oil-importing economy. OPEC Energy Review, 37(2), 125-148. https://doi.org/10.1111/opec. 12010

Mkhalafi, A. (2013). Introduction to Petroleum Economics. University of Kasdi Merbah, Ouargla.

Organisation for Economic Co-operation and Development (OECD). (2017, February 12). Retrieved from https://data.oecd.org/price/inflation-cpi.htm

Valadkhani, A., \& Mitchell, W. F. (2002). Assessing the Impact of Changes in Petroleum Prices on Inflation and Household Expenditures in Australia. Australian Economic Review, 35(2), 122-133. https://doi.org/10.1111/1467-8462.00230

\section{Notes}

Note 1. see indexmundi site( specialized in reviewing major global indicators in a number of sectors including the economic one) 12/2/2017 http://www.indexmundi.com/commodities/?commodity=crude-oil\&months=360.

Note 2. See The website: https://data.oecd.org/price/inflation-cpi.htm 12/2/2017.

\section{Copyrights}

Copyright for this article is retained by the author(s), with first publication rights granted to the journal.

This is an open-access article distributed under the terms and conditions of the Creative Commons Attribution license (http://creativecommons.org/licenses/by/4.0/). 